\title{
RESPONSE OF WHEAT PRODUCTIVITY TO IRRIGATION REGIMES AND NITROGEN FERTILIZATION LEVELS
}

Allam K. ${ }^{1}$, Mohamed H. ${ }^{2}$, Elzopy K. A. ${ }^{3}$, and Sharaf, G. A. ${ }^{4}$

\section{ABSTRACT}

Wheat is the main cereal crop in Egypt. The gap between production and consumption is about $60 \%$. Research efforts are needed to reduce this gap, therefore; the objective of this work was to study the effect of three water regimes as irrigation at 45\%,60\% and 70\% depletion of the available soil moisture, and three nitrogen fertilization levels on two wheat varieties (Giza 168 and Giza 171).The field experiments were carried out at Bahry El-Methaq region, Alexandria Governorate, Egypt during the two successive winter seasons of 2015/2016 and 2016/2017. The experimental design of the study followed split split plot design (SSPD) with three replicates, keeping two bread wheat cultivars \{Giza 168 and Giza 171 \} as the main plots, irrigation regimes (irrigation at 45\%, 60\% and $70 \%$ depletion of the available soil moisture) as subplot, and the three fertilization levels as 100\%, 80\% and 60\% from recommended fertilizer rates of nitrogen fertilization common applied as sub-subplot. The results showed that seasonal ETo was $665.9 \mathrm{~mm}$ for the first season and 624.8 for the second season. Wheat crop transpiration was 600.28 mm at 2015-2016 growing season and $572.95 \mathrm{~mm}$ for the next season. The seasonal applied irrigation water in total was $2702.2 \mathrm{~m}^{3}, 2792.6 \mathrm{~m}^{3}$ and $2879.1 \mathrm{~m}^{3}$ at $45 \%$, $60 \%$ and $70 \%$ depletion treatments for 2015-2016 growing season, respectively. The corresponding values for the next growing season were changed to $2802.5 \mathrm{~m}^{3}, 2687.4 \mathrm{~m}^{3}$ and $2716.4 \mathrm{~m}^{3}$. Based on the irrigation regimes and water balance by the budget technique, the irrigation events of wheat at 45\%, 60\% and 70\% depletion treatments were 29, 23 and 21, which required irrigating for 23.17, 23.94 and 24.69 hours in the first season, respectively.

\footnotetext{
${ }^{1}$ Former chief of research, Agric. Eng. Research Institute, Cairo, Egypt.

${ }^{2}$ Researcher, Agric. Eng. Research Institute, Cairo, Egypt.

${ }^{3}$ Lect., Dept. of Soil Sc. and Agric. Chem., Fac. of Agric., Saba Basha, Alex. U., Egypt. ${ }^{4}$ Prof. of Agric. Eng., Dept. of Soil Sc. and Agric. Chem., Fac. of Agric., Saba Basha, Alex. U, Egypt.
} 
The second season results changed to 28, 23 and 20 irrigations, which required irrigating for 24.4, 22.96 and 23.29 hours. The results indicated that the maximum grain yield and water use efficiency of wheat regardless of the variety under investigation could be obtained with irrigation at $60 \%$ depletion of the available soil moisture and $100 \%$ of the recommended nitrogen fertilization. The yield and water use efficiency of Giza 168 under these conditions were 2.78 ton/fed and $1.02 \mathrm{~kg} / \mathrm{m}^{3}$. While for Giza 171, 3.4 ton/fed and $1.24 \mathrm{~kg} / \mathrm{m}^{3}$ were obtained with $22.3 \%$ and $21.6 \%$ increase in yield and water use efficiency, respectively. The results indicated a significant effect of crop cultivars and nitrogen fertilization levels on biological yield, straw yield, grain yield, WUE of grain yield and WUE of straw yield. Meanwhile, irrigation regimes showed insignificant effect on the previous parameters. The interaction of wheat cultivars, nitrogen fertilization levels and irrigation water regime levels showed insignificant effect on biological yield, straw yield, grain yield, WUE of grain yield and WUE of straw yield.

Keywords: sprinkler irrigation, irrigation schedule, wheat cultivars, water productivity, nitrogen fertilization, Penman Monteith, water balance.

\section{INTRODUCTION}

$\mathrm{W}$ heat is the most important cereal crop in the world in terms of area and production; it is a staple food for more than one third of the world population. In Egypt, wheat is the main winter cereal crop; it is used as a staple food grain for urban and rural societies and the straw is utilized as fodder for animals (Abdelmageed et al., 2019). Wheat consumption has increased drastically due to overall population growth of about $2.0 \%$ per year (World Bank, 2018). Egypt imports about 60 percent of wheat requirements (FAOSTAT, 2017), this reflects the size of the problem and the efforts needed to increase wheat production. Wheat represents almost 10 percent of the total value of agricultural production and about 20 percent of all agricultural imports. Since 2002, wheat has been managed to increase its share of the winter cropped area from around 41 percent to 47 percent. It is well suited to the Egyptian climate where it is grown as a winter crop, often followed by rice or maize in the summer. 
Almost one-third of the total daily calorie intake per person in Egypt is from wheat. To bridge the gap between production and consumption of wheat or other crops in case of limited water resources, irrigation should be precisely managed by selecting a proper method of irrigation, and irrigation scheduling which based on crop requirements and soil properties (Kayam et al., 2000). The irrigation schedule could be based on direct measurement of soil water status, water consumption based on meteorological data and monitoring of plant indicators (Odemiş and Bastug, 1999). According to Allen et al. (1998), the total growing season of winter wheat ranges from 180-250 days to mature. Mean daily temperature for optimum growth is between 15 and 20C $\mathrm{C}^{\circ}$. The crop is moderately tolerant to soil salinity. For high yields its water requirements vary from 450 to $650 \mathrm{~mm}$ depending on climate and length of the growing season. The crop coefficient $(\mathrm{Kc})$; relating maximum evapotranspiration $\mathrm{ET}_{0}$ to crop evapotranspiration ETc, is 0.7 during the initial stage (20 days), from 0.7 to 1.15 during the development stage (50 days), 1.15 during the mid-season stage (60 days) and from 1.15 to 0.4 during the lateseason stage (30 days), (Allen et al., 1998). Noreldin et al. (2015) found that seasonal irrigation water applied for wheat $\left(\mathrm{m}^{3} \mathrm{ha}^{-1}\right)$ under drip irrigation system were 3709,2894 and $2079 \mathrm{~m}^{3} \mathrm{ha}^{-1}$ for 100,75 and $50 \%$ ET, respectively, while for sprinkler irrigation system, 4143, 3405, 2666, 1927 and $1189 \mathrm{~m}^{3} \mathrm{ha}^{-1}$ were applied for 100, 80, 60, 40 and 20\% ET, respectively. Abdelraouf et al. (2014) evaluated the water use efficiency and economic viability of sprinkler irrigation system for wheat crop, the treatments included applying solid set sprinklers and hand move laterals. The irrigation intervals were once per week, twice per week and three times per week. The total irrigation water values varied from 3924 to 4081 $\mathrm{m}^{3} \mathrm{ha}^{-1}$ in 2009-2010 and 4314 to $4486 \mathrm{~m}^{3} \mathrm{ha}^{-1}$ at 2010-2011. The highest seasonal ET was obtained at 2010-2011 as $5417 \mathrm{~m}^{3} \mathrm{ha}^{-1}$, the lowest value was observed at 2009-2010 as $4513 \mathrm{~m}^{3} \mathrm{ha}^{-1}$. The lowest grain yield was $3333 \mathrm{~kg} \mathrm{ha}^{-1}$. Irrigation water use efficiency (IWUE) values varied from 1.0 to $1.43 \mathrm{~kg} \mathrm{~m}^{-3}$ in $2009-2010$ and from 0.87 to $1.34 \mathrm{~kg} \mathrm{~m}^{-3}$ at $2010-2011$. WUE values varied between 0.87 to $1.19 \mathrm{~kg} \mathrm{~m}^{-3}$ at $2009-2010$ and from 0.79 to $1.16 \mathrm{~kg} \mathrm{~m}^{-3}$ at 2010-2011. Adeboye et al. (2015) stated that full irrigation should be practiced to maximize water productivity. Deficit 
irrigation can be used to optimize water productivity. The amount of wheat yield reduction as a result of water stress is affected by the stage of grain development, where early grain development stage is more vulnerable to water stress than latter grain development stage (EL-Kholy et al., 2005). Total cumulative evapotranspiration (ET) of wheat crops typically ranges from 200 to $500 \mathrm{~mm}$, it can be less in non-irrigated semi-arid areas and reach to $600-800 \mathrm{~mm}$ under heavy irrigation.

The aim of the present investigation is to study the effect of three water regime of available water depletion $(45 \%, 60 \%$ and $75 \%)$ and nitrogen fertigation levels on grain and straw yields, and water productivity of two wheat varieties (Giza 168 and Giza 171).

\section{MATERIALS AND METHODS}

The field experimental study was conducted on two wheat cultivars namely, Giza 168 and Giza 171. The experimental field was at Bahry ElMethaq region (altitude: $7 \mathrm{~m}$ above sea level, latitude: $29^{\circ} 0^{\prime} 0^{\prime \prime} \mathrm{N}$, and longitude: $31^{\circ} 7^{\prime}$ 0" E), Bourg El-Arab, Alexandria Governorate, Egypt. The experiment was conducted during two successive winter seasons from 15 November to 23 April 2015/2016 and 12 November to 20 April $2016 / 2017$. The experimental design was split split plot (SSPD) with three replicates, keeping wheat cultivars $\left\{\right.$ Giza $168\left(\mathrm{C}_{1}\right)$, and Giza $\left.171\left(\mathrm{C}_{2}\right)\right\}$ as the main plots, irrigation regimes (irrigation at 45\%, 60\%, 70\% depletion of the allowable soil moisture limit) as subplot. Three fertilization levels as $100 \%, 80 \%$ and $60 \%$ from recommended fertilizer rates of nitrogen fertilization common applied were as sub-subplot. The procedure, materials and methods applied during the study were as follows:

\section{Water budget technique}

The scheduling of irrigation by water budget was based on the water balance in soil within a specific limit of soil moisture content depending on soil and plant characteristics in addition to weather climatic data to estimate the crop consumptive use. The water budget technique in determining when to irrigate involves calculating the current water moisture content of the soil instead of measuring it, then comparing it to predetermined minimum $\theta_{c}=\theta_{F C}-\left(\theta_{F C}-\theta_{W P}\right) \times d r$ 
water content and irrigating to maintain soil water above the minimum level (critical). The critical water content was determined by the following equation:

where:

$\theta c \quad$ soil critical moisture content (\%),

$\theta_{F C}$ soil moisture content at field capacity (\%),

$\theta_{W P}$ soil moisture content at the wilting point (\%), and

$d r$ depletion ratio, which was taken as $0.45,0.6$ and 0.7 .

The current water content of the soil was computed by the following equation:

$$
\theta_{i}=\theta_{i-1}-\left(\frac{E T_{c}-E R}{10 \times R d(1-L R)}\right)_{i}
$$

where:

$\theta_{i}, \theta_{i-1}$ soil water content (\%) at the end of the day $\mathrm{i}$ and day $\mathrm{i}-1$, respectively

$E T_{c}$ daily crop evapotranspiration (mm/day)

$R d$ effective root depth (m)

$L R$ ratio of leaching requirements

$E R$ effective rain (mm/day)

Leaching requirements $(L R)$ of the soil were estimated according to Doorenbos and Pruitt (1977) by the following equation:

$$
L R=\frac{E C_{w}}{5 E C_{e}-E C_{w}}
$$

where:

$E C_{e}$ electrical conductivity of the saturation extract.

$E C_{w}$ electrical conductivity of the irrigation water,

Once the time to irrigate has been determined, the usual practice was to fill the root zone to the field capacity by applying required irrigation depth as follow:

$$
I A W=\frac{10 \times R d\left(\theta_{F C}-\theta_{c}\right)}{\eta}
$$


where:

$I A W$ depth of irrigation water $(\mathrm{mm})$,

$\theta_{\mathrm{c}} \quad$ volumetric water content (\%) directly prior to irrigation.

$\eta$ system irrigation efficiency (decimal).

The irrigation time was determined by following equation:

$$
T i=\frac{I A W}{I}
$$

where:

Ti irrigation time (hr/period)

I sprinkler application rate $(\mathrm{mm} / \mathrm{hr})$

The application rate by sprinkler was determined by:

$$
I=\frac{q \times 1000}{S \times L}
$$

where:

q sprinkler discharge $\left(\mathrm{m}^{3} / \mathrm{hr}\right)$

$\mathrm{S}$ distance between sprinklers (m)

$\mathrm{L}$ distance between laterals $(\mathrm{m})$

The daily wheat crop water requirement of wheat was estimated by:

$$
E T_{c}=E T_{o} * K c
$$

where:

$E T_{o}$ daily reference evapotranspiration ( $\mathrm{mm} /$ day).

$K c$ daily crop coefficient.

Reference evapotranspiration ( $\left.\mathrm{ET}_{0}\right)$ was calculated by using the weather data of the local meteorological weather station for 2015-2016 and 201629017 seasons according to Penman-Monteith method (Allen et al., 1998) as follows:

$$
\text { ETo }=\frac{0.408 \Delta\left(R_{n}-G\right)+\gamma \frac{900}{T+273} u_{2}\left(e_{s}-e_{a}\right)}{\Delta+\gamma\left(1+0.34 u_{2}\right)}
$$


where:

ETo potential evapotranspiration ( $\mathrm{mm} /$ day),

$R_{n}$ net radiation at the crop surface $\left(\mathrm{MJ} / \mathrm{m}^{2}\right.$ day),

$G$ soil head flux density ( $\mathrm{MJ} / \mathrm{m}^{2}$ day),

$T$ mean daily air temperature $\left({ }^{\circ} \mathrm{C}\right)$ measured at $2 \mathrm{~m}$ height,

$U_{2}$ wind speed $(\mathrm{m} / \mathrm{s})$ at $2 \mathrm{~m}$ height,

$E_{s} \quad$ saturation vapor pressure $(\mathrm{kPa})$,

$e_{a}$ actual vapor pressure $(\mathrm{kPa})$,

$e_{s}-e_{a}$ vapor pressure deficit $(\mathrm{kPa})$,

$\Delta$ slope of the vapor pressure curve $\left(\mathrm{kPa} /{ }^{\circ} \mathrm{C}\right)$, and

$\Gamma$ psychometric constant $\left(\mathrm{kPa} /{ }^{\circ} \mathrm{C}\right)$.

The daily value of crop coefficient of wheat (Kc) considered constant as 0.7 along the initial stage for 30 days, meanwhile 1.15 along 60 days along the midseason stage. In development and late season, the crop coefficient changes linearly along these two stages. The following equation was used to get the daily value as follow (Allen et al., 1998):

$$
K c(i)=K c_{\text {prev. }}+\left[\frac{i-\sum L_{\text {prv. }}}{L_{\text {stage }}}\right]\left(K c_{\text {next }}-K c_{\text {prev }}\right)
$$

where:

$K c(i) \quad$ crop coefficient of the day No. $\mathrm{i}$

$K c_{\text {prev }} \mathrm{Kc}$ value of the previous stage

$L_{\text {stage }}$ length of the stage under consideration (days)

$\Sigma\left(L_{\text {prev }}\right) \quad$ sum of the lengths of the previous stages (days)

$K c_{n e x t} \mathrm{Kc}$ value of the next stage

\section{Effective root depth $\left(\boldsymbol{R}_{d}\right)$}

The estimation of wheat effective root depth $(\mathrm{Rd})$ was based on local observations of neighborhood fields for the same cultivars and cultivated at the same conditions. The maximum depth of roots was obtained after 100 day from planting. According to Duke et al. (1985) the root depth was assumed to increase linearly as a function of time from specified minimum root depth at "root development date" to a maximum root depth at the "effective cover date". Based on this assumption and the local 
observations, the computation of the effective root depth was estimated during the crop growing seasons according to the formula:

$$
\begin{array}{ll}
R d_{i}=R d_{\text {ini }}+\frac{D_{i}-D_{p}}{D_{\max }-D_{p}}\left(R d_{\max }-R d_{\text {ini }}\right) & D_{i}<D_{\max } \\
R d_{i}=R d_{\max } & D_{i} \geq D_{\max }
\end{array}
$$

where:

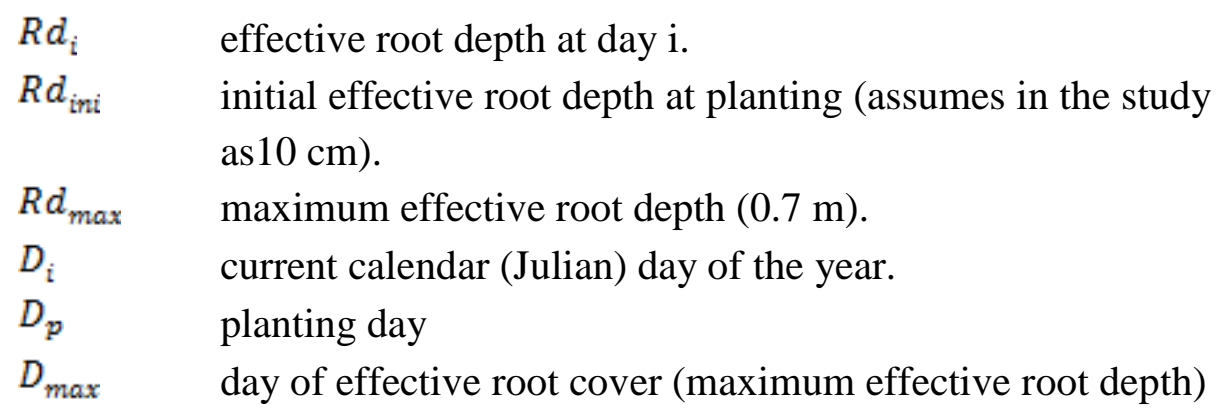

\section{Crops:}

The trading name and pedigree of wheat bread wheat cultivars are presented in Table (1). The study on the two-wheat cultivar was conducted during two successive winter seasons of 2015/2016 and 2016/2017. The sowing date was at 15 November and the harvest was at 23 April during the growing season of 2015/2016, the next growing season started at 12 November and continued till 20 April. The cultivation practices were conducted during the two successive seasons according to the recommended agricultural practices for the region.

Tab. (1): The treading name and pedigree of the wheat cultivars.

\begin{tabular}{|c|c|c|}
\hline Symbol & Cultivars & Pedigree \\
\hline C1 & Giza 168 & $\begin{array}{c}\text { MRL/BUC//SERI CM93046-8M-0Y-0M-2Y-0B- } \\
\text { 0GZ }\end{array}$ \\
\hline C2 & Giza 171 & SAKHA 93 / GEMMEIZA 9 \\
\hline
\end{tabular}

\section{Soil:}

Soil samples were collected from four different randomized locations at two different soil depths in range of $0-30 \mathrm{~cm}$ and $30-60 \mathrm{~cm}$. These samples were analyzed at Nubaria Research Station. Soil physical properties (Table, 2), were determined according to Black et al. (1982). The field was prepared thoroughly by plowing and harrowing then removing the 
different types of plant debris then calcium super phosphate $\left(15.5 \% \mathrm{P}_{2} \mathrm{O}_{5}\right)$ at the rate of $200 \mathrm{~kg} / \mathrm{fad}$ and potassium sulfate $\left(48.5 \% \mathrm{~K}_{2} \mathrm{O}\right)$ at the rate of $50 \mathrm{~kg} / \mathrm{fad}$ were broadcasted. Wheat grains were hand sewn at the rate of $60 \mathrm{~kg} / \mathrm{fad}$. After planting, all other cultural practices for wheat crop were carried out according to the recommended for the region. It also pulverized and leveled. Harvesting was after 160 days from sowing for the both seasons.

\section{Irrigation Systems:}

A fixed sprinkler irrigation system was used to conduct the field experiment study. The components and specifications of the system are summarized in Table (3). The sprinkler jet discharge was volumetrically measured by placing two flexible hoses over the sprinkler nozzles and receiving the flowing water in calibrated containers (20 liters). The time to fill the container was recorded by digital stopwatch, and the discharge was calculated as $\mathrm{m}^{3} / \mathrm{h}$. The sprinkler base pressure was measured using a hypodermic needle assembly and dial pressure gage as indicated by the ASAE (1988) standard.

Tab. (2): Soil physical properties for experimental site.

\begin{tabular}{lccc} 
Soil depth $(\mathbf{c m})$ & $\mathbf{0 - 3 0}$ & $\mathbf{3 0 - 6 0}$ & Average \\
\hline Sand & 73.5 & 73.0 & 73.25 \\
Silt & 15.5 & 14.6 & 15.05 \\
Clay & 11.0 & 12.4 & 11.7 \\
Soil texture & Sandy loam & Sandy loam & Sandy loam \\
Bulk density $\left(\mathrm{g} \cdot \mathrm{cm}^{-3}\right)$ & 1.57 & 1.51 & 1.54 \\
$\boldsymbol{\theta}_{\mathbf{s}}\left(\mathrm{m}^{3} \cdot \mathrm{m}^{-3}\right)$ & 0.44 & 0.43 & 0.435 \\
F.C. $\left(\mathrm{m}^{3} \cdot \mathrm{m}^{-3}\right)$ & 0.215 & 0.195 & 0.205 \\
P.W.P $\left(\mathrm{m}^{3} \cdot \mathrm{m}^{-3}\right)$ & 0.12 & 0.115 & 0.1175 \\
A.W. $\left(\mathrm{m}^{3} \cdot \mathrm{m}^{-3}\right)$ & 0.095 & 0.08 & 0.0875 \\
$\boldsymbol{k}_{\boldsymbol{s}}\left(\mathrm{mm} \cdot \mathrm{hr}^{-1}\right)$ & 44.5 & 46.1 & 45.3 \\
\hline
\end{tabular}


Tab. (3): Components and specifications of the sprinkler irrigation system at the experimental site.

\section{Component}

Sprinkler type

Nozzle size $(\mathrm{mm})$

Raiser height (cm)

Steel riser diameter $(\mathrm{mm})$

Operating pressure $(\mathrm{kPa})$

Ave. sprinkler discharge $\left(\mathrm{m}^{3} / \mathrm{h}\right)$

Sprinkler spacing (m)

No. of sprinklers per lateral

Wetting diameter $(\mathrm{m})$

PVC. lateral diameter $(\mathrm{mm})$

laterals operating together

PVC main line diam. (mm)

Pump discharge $\left(\mathrm{m}^{3} / \mathrm{h}\right)$

Pump pressure head $(\mathrm{kPa})$

Power of elect. motor $(\mathrm{kW})$

motor pump speed (rpm)

\section{Specification}

Aqua (Indian)

$\varnothing 10.30 \times 5.60$

120

33.4

350

9

$18 \times 18$

4

46.4

90

2

125

72

540

18.5

1450

\section{Statistical design and tested treatments:}

A split split plot design (SSPD) with three replicates was adopted in the current study as follow:

a) Two wheat cultivars \{Giza $168\left(\mathrm{C}_{1}\right)$, and Giza $\left.171\left(\mathrm{C}_{2}\right)\right\}$ was allocated in the main plots.

b) Three irrigation regimes \{irrigation at $45 \%\left(\mathrm{AWD}_{45 \%}\right), 60 \%$ $\left(\mathrm{AWD}_{60 \%}\right)$ and $70 \%\left(\mathrm{AWD}_{70 \%}\right)$ depletion of the available soil moisture in the subplot.

c) Three fertigation levels $(100 \%, 80 \%$ and $60 \%$ from recommended fertilizer rates of nitrogen fertilization) in the sub-subplot.

\section{Water productivity WP:}

The water productivity ( $\mathrm{WP} ; \mathrm{kg} / \mathrm{m}^{3}$ ) was calculated according to Jensen (1983) as a ratio between the grain yield per fed (kg/fed) over the gross applied irrigation water per fed $\left(\mathrm{m}^{3} / \mathrm{fed}\right)$. 


\section{Yield and yield components.}

At harvest, the central six rows of each plot, with four meters long, were harvested and the data were recorded for grain yield and biological yield.

\section{Data analysis:}

The data were analyzed using Costat 6.311 win statistical program CoHort Software (2005). Average values from the three replicates of each treatment were interpreted using the analysis of variance (ANOVA). The Duncan's Multiple Range Test (SNK) was used for comparisons among different sources of variance.

\section{RESULTS AND DISCUSSIONS}

\section{Sprinkler validity:}

The application rate by the sprinkler (I) was $27.78 \mathrm{~mm} / \mathrm{hr}$. To ensure the suitability of the sprinkler application rate for avoiding surface water runoff, the application rate by the sprinkler was compared with the soil basic infiltration rate or the soil saturated hydraulic conductivity (45.3 $\mathrm{mm} / \mathrm{hr}$ ). The results indicated that the ratio is less than $2 / 3$, which means that the sprinkler is totally safe for avoiding runoff losses and eliminating free water evaporation from the soil surface.

\section{Potential evapotranspiration (ET0):}

Daily $\mathrm{ET}_{0}(\mathrm{~mm} /$ day) along the two growing seasons of wheat was calculated by Penman-Monteith Eq. (9) and applying the weather data of mean temperature, mean relative humidity and wind speed during 2015/2016 and 2016/2017 seasons (Fig.,1; Fig., 2). Due to lack of the previous weather data from measurements of short wave radiation or the actual sun duration, an assumption of actual to maximum sun duration $(\mathrm{n} / \mathrm{N})$ was used as 0.77 and the equations of appendix I were used to determine the reference evapotranspiration by Excel spreadsheets. Results of daily $\mathrm{ET}_{0}$ along the 2015-2016 and 2016-2017 growing seasons are presented in Fig. (1) and Fig. (2), respectively. Seasonal ET 0 was 665.9 $\mathrm{mm}$ for the first season and 624.8 for the second season. The average daily $\mathrm{ET}_{0}$ were 4.16 and 3.91 for the same previous order.

\section{Evapotranspiration of the wheat (ETc):}

Daily ETc of the wheat was estimated by Eq. (8). The daily ETc of wheat along the two growing seasons are presented in Fig. (1) and Fig. (2). The 
results showed that, ETc values were gradually decreased as the plant age progressed till the midseason stage, then the rate was increased till the end of the growing season.
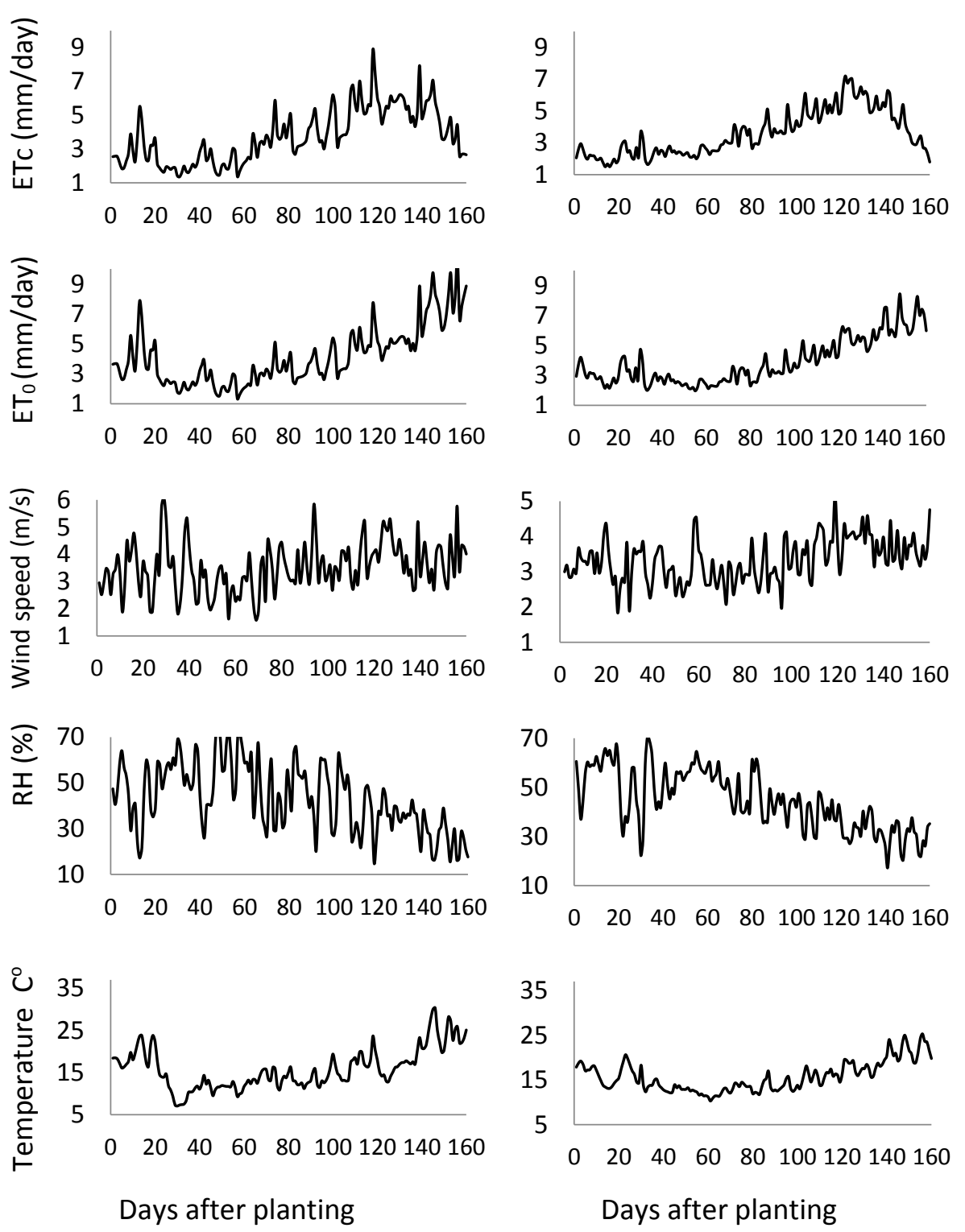

Fig. (1): Weather data, $E_{0}$ and ETc along the 2015-2016 growing season of wheat.

Fig. (2): Weather data, ET 0 and ETc along the 2016-2017 growing season of wheat. 
The reason of such trend is due to decreased temperature, relative humidity, wind speed and $\mathrm{ET}_{0}$. The seasonal ETc was $600.28 \mathrm{~mm}$ for 2015-2016 growing season and $572.95 \mathrm{~mm}$ for the next season. Average value of ETc was $3.76 \mathrm{~mm}$ during 2016-2017 growing season and 3.55 $\mathrm{mm}$ at the second season.

\section{Irrigation applied water $(I A W)$ :}

The irrigation water was applied to wheat according to the proposed irrigation regimes and the water budget balance as $\mathrm{AWD}_{45 \%}, \mathrm{AWD}_{60 \%}$ and $\mathrm{AWD}_{70 \%}$ treatments. The seasonal irrigation applied water (including 30\% as leaching requirements and the effective rain) were $643.4 \mathrm{~mm}(2702.2$ $\left.\mathrm{m}^{3} / \mathrm{fed}\right), 646.9 \mathrm{~mm}\left(2792.6 \mathrm{~m}^{3} / \mathrm{fed}\right)$ and $685.5 \mathrm{~mm}\left(2879.1 \mathrm{~m}^{3} / \mathrm{fed}\right)$ for the 2015-2016 growing season at $\mathrm{AWD}_{45 \%}, \mathrm{AWD}_{60 \%}$ and $\mathrm{AWD}_{70 \%}$ treatments, respectively. The amounts changed to $667.3 \mathrm{~mm}\left(2802.5 \mathrm{~m}^{3} / \mathrm{fed}\right), 637.7 .9$ $\mathrm{mm}\left(2687.4 \mathrm{~m}^{3} / \mathrm{fed}\right)$ and $646.75 \mathrm{~mm}\left(2716.4 \mathrm{~m}^{3} / \mathrm{fed}\right)$ at the next growing season. The dates of irrigation events, depth of water per irrigation, the sprinkler system operating time per irrigation as a result of the daily water budget analyses of 2015-2016 and 2016-2017 growing seasons are given in Tab. (4) and Tab. (5), respectively. The last $10-14$ days before harvesting, the irrigation was terminated to decrease the moisture contents of the grain to dry enough for suitable harvesting. The fluctuations of irrigation applied water along the growing seasons were referred to the changes in climatic conditions, plant water requirements and plant growth.

\section{Soil moisture balance results by budget technique:}

The logic of the water balance method in soil water analyses depends on replenishing the depleted water in the root zone once it reaches a specific critical soil moisture content that predefined by the user. In the current study, the criteria of irrigation depended on replenishing the soil moisture once it reaches $45 \%\left(\mathrm{AWD}_{45 \%}\right), 60 \%\left(\mathrm{AWD}_{60 \%}\right)$ and $70 \%\left(\mathrm{AWD}_{70 \%}\right)$ depletion of the soil available water. Under these circumstances, an irrigation event should be carried out once the soil moisture reaches to $16.4 \%, 15.38 \%$ and $14.35 \%$ in $\mathrm{AWD}_{45 \%}, \mathrm{AWD}_{60 \%}$ and $\mathrm{AWD}_{70 \%}$ treatments, respectively. The plant daily consumptive use, effective rain and leaching requirements were considered when the daily depletion was determined. The next step was to calculate the irrigation depth that returns 
the soil moisture back to soil field capacity, considering the irrigation system efficiency.

Tab. (4): Depth of gross irrigation water and operating time of irrigation by water balance under different irrigation water regimes for 20152016 growing season.

\begin{tabular}{|c|c|c|c|c|c|c|c|c|}
\hline \multicolumn{3}{|c|}{ RIGIEM No.1 (AWD $45 \%)$} & \multicolumn{3}{|c|}{ RIGIEM No.2 (AWD $60 \%)$} & \multicolumn{3}{|c|}{ RIGIEM No.3 (AWD A $\left._{70 \%}\right)$} \\
\hline Date & $\begin{array}{c}\text { Gross } \\
\text { water/irri. } \\
\mathrm{mm}\end{array}$ & $\begin{array}{c}\text { Operating } \\
\text { time } \\
\text { hr/irri }\end{array}$ & Date & $\begin{array}{c}\text { Gross } \\
\text { water/irri. } \\
\mathrm{mm}\end{array}$ & $\begin{array}{c}\text { Operating } \\
\text { time } \\
\text { hr/irri }\end{array}$ & Date & $\begin{array}{c}\text { Gross } \\
\text { water/irri. } \\
\mathrm{mm}\end{array}$ & $\begin{array}{c}\text { Operating } \\
\text { time } \\
\text { hr/irri }\end{array}$ \\
\hline $15 / 11$ & 8.75 & 0.32 & $15 / 11$ & 8.75 & 0.32 & $15 / 11$ & 8.75 & 0.32 \\
\hline $17 / 11$ & 5.30 & 0.19 & $17 / 11$ & 5.30 & 0.19 & $17 / 11$ & 5.30 & 0.19 \\
\hline $20 / 11$ & 6.38 & 0.23 & $20 / 11$ & 6.38 & 0.23 & $21 / 11$ & 10.55 & 0.38 \\
\hline $22 / 11$ & 4.70 & 0.17 & $22 / 11$ & 4.70 & 0.17 & $26 / 11$ & 8.54 & 0.31 \\
\hline $26 / 11$ & 2.24 & 0.08 & $27 / 11$ & 9.84 & 0.35 & $28 / 11$ & 11.32 & 0.41 \\
\hline $30 / 11$ & 10.48 & 0.38 & $30 / 11$ & 10.48 & 0.38 & $04 / 12$ & 15.40 & 0.55 \\
\hline $04 / 12$ & 6.71 & 0.24 & $05 / 12$ & 14.41 & 0.52 & $10 / 12$ & 20.21 & 0.73 \\
\hline $08 / 12$ & 12.12 & 0.44 & $10 / 12$ & 15.37 & 0.55 & $20 / 12$ & 24.00 & 0.86 \\
\hline $14 / 12$ & 14.85 & 0.53 & $18 / 12$ & 20.27 & 0.73 & $26 / 12$ & 25.94 & 0.93 \\
\hline $21 / 12$ & 17.75 & 0.64 & $25 / 12$ & 24.47 & 0.88 & $04 / 01$ & 32.23 & 1.16 \\
\hline $25 / 12$ & 14.44 & 0.52 & $31 / 12$ & 24.87 & 0.90 & $22 / 01$ & 43.65 & 1.57 \\
\hline $30 / 12$ & 19.81 & 0.71 & $20 / 01$ & 34.13 & 1.23 & $30 / 01$ & 41.48 & 1.49 \\
\hline $06 / 01$ & 22.70 & 0.82 & $27 / 01$ & 39.16 & 1.41 & $12 / 02$ & 47.27 & 1.70 \\
\hline $20 / 01$ & 28.90 & 1.04 & $11 / 02$ & 38.29 & 1.38 & $22 / 02$ & 50.07 & 1.80 \\
\hline $25 / 01$ & 29.64 & 1.07 & $21 / 02$ & 48.40 & 1.74 & $03 / 03$ & 60.92 & 2.19 \\
\hline $31 / 01$ & 26.55 & 0.96 & $27 / 02$ & 45.88 & 1.65 & $10 / 03$ & 56.92 & 2.05 \\
\hline $09 / 02$ & 29.74 & 1.07 & $06 / 03$ & 41.14 & 1.48 & $15 / 03$ & 55.49 & 2.00 \\
\hline $14 / 02$ & 28.99 & 1.04 & $12 / 03$ & 50.04 & 1.80 & $21 / 03$ & 54.66 & 1.97 \\
\hline $22 / 02$ & 34.26 & 1.23 & $17 / 03$ & 48.40 & 1.74 & $28 / 03$ & 58.29 & 2.10 \\
\hline $27 / 02$ & 33.09 & 1.19 & $22 / 03$ & 47.20 & 1.70 & $05 / 04$ & 54.61 & 1.97 \\
\hline $05 / 03$ & 32.30 & 1.16 & $28 / 03$ & 46.34 & 1.67 & & & \\
\hline $09 / 03$ & 32.90 & 1.18 & $04 / 04$ & 43.97 & 1.58 & & & \\
\hline $13 / 03$ & 39.30 & 1.42 & $08 / 04$ & 37.08 & 1.34 & & & \\
\hline $17 / 03$ & 33.04 & 1.19 & & & & & & \\
\hline $21 / 03$ & 35.20 & 1.27 & & & & & & \\
\hline $25 / 03$ & 37.03 & 1.33 & & & & & & \\
\hline $02 / 04$ & 35.57 & 1.28 & & & & & & \\
\hline $07 / 04$ & 40.61 & 1.46 & & & & & & \\
\hline$\sum$ & 643.37 & 23.17 & $\sum$ & 664.89 & 23.94 & $\sum$ & 685.60 & 24.69 \\
\hline
\end{tabular}


Tab. (5): Depth of gross irrigation water and operating time of irrigation by water balance under different irrigation water regimes for 20162017 growing season.

\begin{tabular}{|c|c|c|c|c|c|c|c|c|}
\hline \multicolumn{3}{|c|}{ RIGIEM No.1 (AWD $45 \%)$} & \multicolumn{3}{|c|}{ RIGIEM No.2 (AWD $60 \%$ ) } & \multicolumn{3}{|c|}{ RIGIEM No.3 (AWD $70 \%$ ) } \\
\hline Date & $\begin{array}{c}\text { Gross } \\
\text { water/irri. } \\
\mathrm{mm}\end{array}$ & $\begin{array}{c}\text { Operating } \\
\text { time } \\
\text { hr/irri }\end{array}$ & Date & $\begin{array}{c}\text { Gross } \\
\text { water/irri. } \\
\mathrm{mm}\end{array}$ & $\begin{array}{c}\text { Operating } \\
\text { time } \\
\text { hr/irri }\end{array}$ & Date & $\begin{array}{c}\text { Gross } \\
\text { water/irri. } \\
\mathrm{mm}\end{array}$ & $\begin{array}{c}\text { Operating } \\
\text { time } \\
\text { hr/irri }\end{array}$ \\
\hline $15 / 11$ & 8.75 & 0.45 & $15 / 11$ & 8.75 & 0.45 & $15 / 11$ & 8.75 & 0.32 \\
\hline $17 / 11$ & 5.38 & 0.28 & $17 / 11$ & 5.38 & 0.28 & $17 / 11$ & 5.38 & 0.19 \\
\hline $19 / 11$ & 5.37 & 0.28 & $19 / 11$ & 5.37 & 0.28 & $20 / 11$ & 10.09 & 0.36 \\
\hline $21 / 11$ & 4.06 & 0.21 & $22 / 11$ & 8.83 & 0.45 & $23 / 11$ & 9.29 & 0.33 \\
\hline $23 / 11$ & 4.51 & 0.23 & $25 / 11$ & 8.68 & 0.45 & $27 / 11$ & 12.69 & 0.46 \\
\hline $26 / 11$ & 8.18 & 0.42 & $29 / 11$ & 11.32 & 0.58 & $02 / 12$ & 13.79 & 0.50 \\
\hline $30 / 11$ & 10.50 & 0.54 & $04 / 12$ & 14.91 & 0.77 & $06 / 12$ & 13.47 & 0.49 \\
\hline $04 / 12$ & 11.53 & 0.59 & $07 / 12$ & 11.94 & 0.61 & $11 / 12$ & 21.71 & 0.78 \\
\hline $07 / 12$ & 11.94 & 0.61 & $11 / 12$ & 14.82 & 0.76 & $15 / 12$ & 17.84 & 0.64 \\
\hline $11 / 12$ & 14.82 & 0.76 & $15 / 12$ & 17.84 & 0.92 & $24 / 12$ & 27.86 & 1.00 \\
\hline $14 / 12$ & 9.96 & 0.51 & $23 / 12$ & 22.24 & 1.14 & $31 / 12$ & 29.97 & 1.08 \\
\hline $18 / 12$ & 14.47 & 0.74 & $29 / 12$ & 26.35 & 1.36 & $12 / 01$ & 34.50 & 1.24 \\
\hline $24 / 12$ & 15.49 & 0.80 & $08 / 01$ & 30.38 & 1.56 & $22 / 02$ & 60.67 & 2.18 \\
\hline $29 / 12$ & 20.96 & 1.08 & $20 / 02$ & 44.26 & 2.28 & $01 / 03$ & 52.85 & 1.90 \\
\hline $06 / 01$ & 20.82 & 1.07 & $26 / 02$ & 44.25 & 2.28 & 07/03 & 51.21 & 1.84 \\
\hline $14 / 01$ & 26.26 & 1.35 & $04 / 03$ & 48.77 & 2.51 & $14 / 03$ & 60.93 & 2.19 \\
\hline $19 / 02$ & 36.97 & 1.90 & $09 / 03$ & 41.76 & 2.15 & $19 / 03$ & 56.40 & 2.03 \\
\hline $24 / 02$ & 32.97 & 1.70 & $15 / 03$ & 49.98 & 2.57 & $26 / 03$ & 55.49 & 2.00 \\
\hline $01 / 03$ & 36.03 & 1.85 & $19 / 03$ & 43.14 & 2.22 & $01 / 04$ & 51.05 & 1.84 \\
\hline $06 / 03$ & 40.53 & 2.09 & $25 / 03$ & 42.62 & 2.19 & $11 / 04$ & 52.81 & 1.90 \\
\hline $11 / 03$ & 38.84 & 2.00 & $30 / 03$ & 43.42 & 2.23 & & & \\
\hline $15 / 03$ & 32.73 & 1.68 & $08 / 04$ & 47.56 & 2.45 & & & \\
\hline $18 / 03$ & 28.75 & 1.48 & $14 / 04$ & 45.14 & 2.32 & & & \\
\hline $23 / 03$ & 36.68 & 1.89 & & & & & & \\
\hline $27 / 03$ & 37.66 & 1.94 & & & & & & \\
\hline $01 / 04$ & 40.93 & 2.11 & & & & & & \\
\hline $09 / 04$ & 35.23 & 1.81 & & & & & & \\
\hline $14 / 04$ & 37.09 & 1.91 & & & & & & \\
\hline$\sum$ & 667.25 & 24.03 & $\sum$ & 637.72 & 22.96 & $\sum$ & 646.75 & 23.29 \\
\hline
\end{tabular}


Sometimes after heavy rains, the soil moisture exceeded the field capacity to the saturation zone. In this case, the soil moisture was considered at the field capacity by the end of the day as recommended by Allen et al. (1998). This is true because the gravitational water moves to deep percolation rapidly especially in sandy soil and the plant root does not absorb water over the field capacity limits. Results of daily moisture content of the suggested water regime during the growing seasons of 2015-2016 and 2016-2017 are presented in Fig. (3) and Fig (4), respectively. The validity of the method was studied by Berry et al. (2004) and proved that the method is fair enough to predict the soil moisture content by soil water balance.

\section{Wheat productivity and water use efficiency:}

By the end of each growing season, biological yield straw yield and grain yield were determined under the three irrigation regimes and the three nitrogen fertilization levels for Giza 168 and Giza 171 varieties during the 2015-2016 and 2016-2017 growing seasons (Table, 6). The two seasons average of irrigation applied water and yield components of wheat are given in Table (7). The results indicated that the maximum yield, yield components and water use efficiency regardless of the wheat variety were obtained with the irrigation at $\mathrm{AWD}_{60 \%}$ and nitrogen fertilization at $100 \%$ of recommended. The average biological yield, straw yield and grain yield of Giza 168 were 9.82 ton/fed, 6.5 ton/fed and 2.78 ton/fed, respectively. While, the same parameters of wheat Giza 171 were 11.69 ton/fed, 8.28 ton/fed and 3.4 ton/fed. Results of WUE for biological yield (Twue), straw yield (Swue) and grain yield (Gwue) are presented in Fig. (5). For wheat Giza 168 maximum Twue, Swue and Gwue were $3.39 \mathrm{~kg} / \mathrm{m}^{3}, 2.78 \mathrm{~kg} / \mathrm{m}^{3}$ and $1.02 \mathrm{~kg} / \mathrm{m}^{3}$ with $\mathrm{AWD}_{60 \%}$ irrigation regime and $100 \%$ nitrogen fertilization, respectively. These values increased to be $4.27 \mathrm{~kg} / \mathrm{m}^{3}, 3.40$ $\mathrm{kg} / \mathrm{m}^{3}$ and $1.25 \mathrm{~kg} / \mathrm{m}^{3}$ for wheat Giza 171. The results in Tab. (7) also indicated that the maximum yield parameters of wheat Giza 171 were higher than Giza 168 by $26.0 \%, 27.4 \%$ and $22.3 \%$ for biological, straw and grain yields, respectively. 


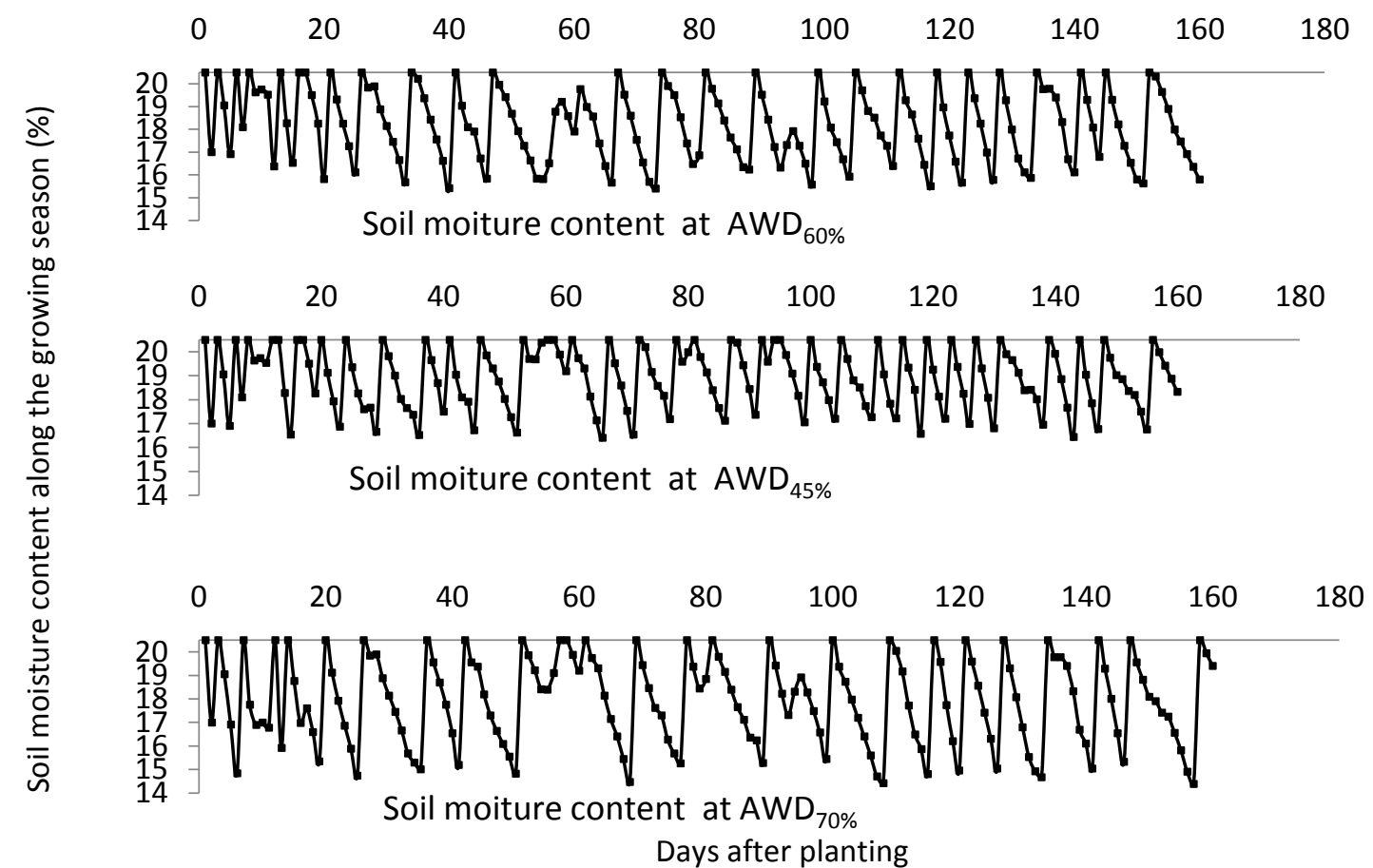

Fig. (3): Soil moisture content along the 2015-2016 growing season of wheat.

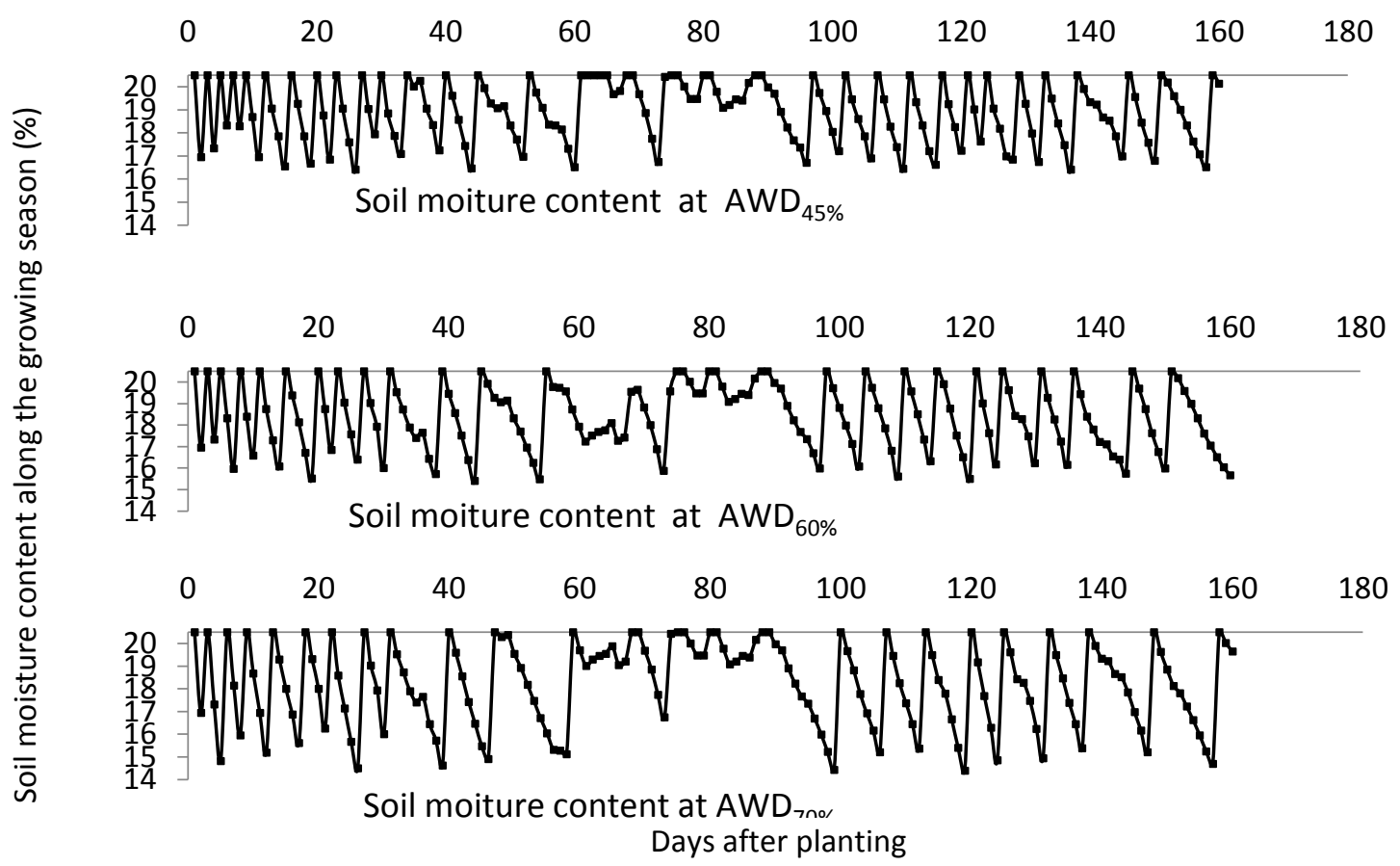

Fig. (4): Soil moisture content along the 2016-2017 growing season of wheat. 


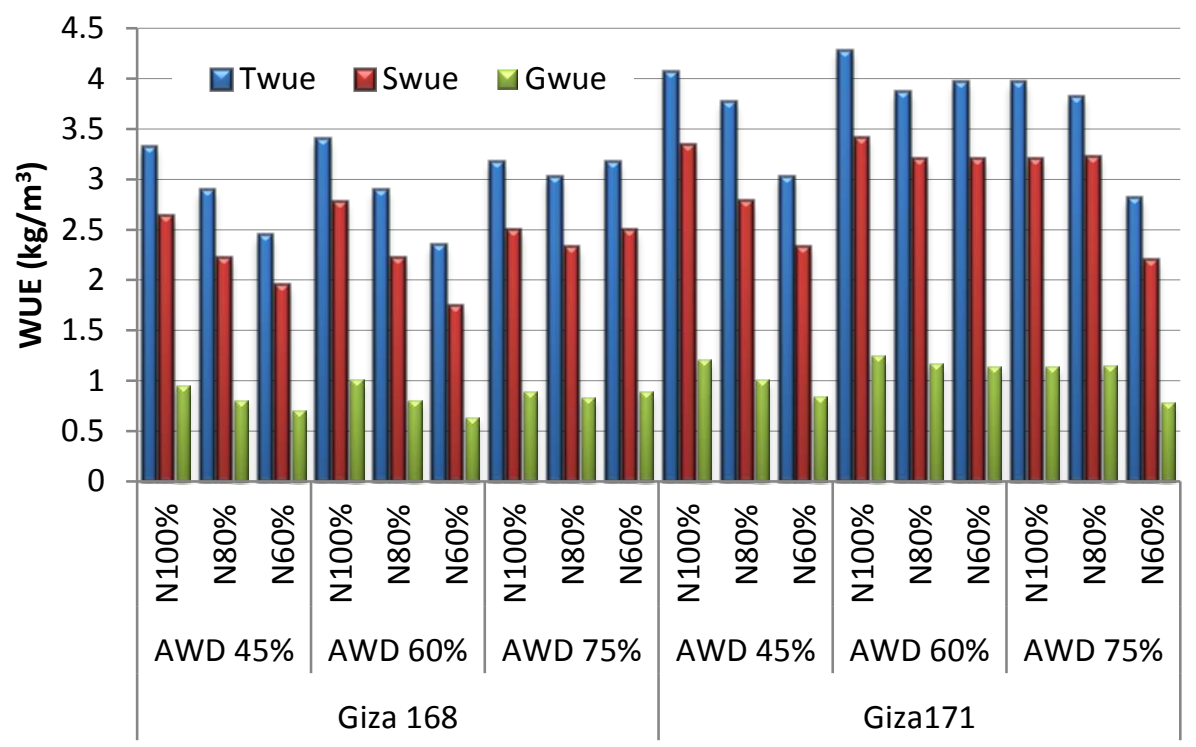

Fig. (5): WUE of biological, straw and grain yields versus fertilization and water regime.

\section{The statistical analyses results:}

The statistical analyses results showed that a significant effect due to crop cultivars and nitrogen fertilization levels on biological yield, straw yield, grain yield, water use efficiency of grain yield and water use efficiency of straw yield. Meanwhile irrigation water regime levels showed insignificant effect on the previous parameters. The interaction of wheat cultivars, nitrogen fertilization levels and irrigation water regime levels showed insignificant effect on biological yield, straw yield, grain yield, water use efficiency of grain yield and water use efficiency of straw yield. The interaction of wheat cultivars and irrigation water regime showed insignificant effect on biological yield, grain yield and WUE of grain and straw yields at the growing season of 2015-2016. The same behaviors observed at the next growing season expect significant effect noticed on both grain yield and WUE of the grain yield. The interaction of the nitrogen fertilization level and irrigation water regime indicated insignificant effect on biological yield, straw yield and WUE of the straw yield. The complete results of the statistical analyses are given in Tables 1, 2 Appendix II. 
Tab. (6): Yield components of wheat Giza 168 and 171 as influenced by irrigation regime and nitrogen fertilization level.

\begin{tabular}{|c|c|c|c|c|c|c|c|c|}
\hline \multirow{2}{*}{$\begin{array}{l}\text { Wheat } \\
\text { variety }\end{array}$} & \multirow{2}{*}{$\begin{array}{l}\text { Water } \\
\text { regime }\end{array}$} & \multirow{2}{*}{$\stackrel{\mathrm{N}}{\mathrm{N}}$} & \multicolumn{2}{|c|}{$\begin{array}{l}\text { Biological } \\
\text { yield ton/fed }\end{array}$} & \multicolumn{2}{|c|}{$\begin{array}{l}\text { Grain yield } \\
\text { Ton/fed }\end{array}$} & \multicolumn{2}{|c|}{$\begin{array}{c}\text { Gross irrigation } \\
\text { water } \mathrm{m}^{3} / \mathrm{fed}\end{array}$} \\
\hline & & & $\begin{array}{l}2015- \\
2016\end{array}$ & $\begin{array}{l}2016- \\
2017\end{array}$ & $\begin{array}{l}2015 \\
2016\end{array}$ & $\begin{array}{l}2016- \\
2017\end{array}$ & $\begin{array}{l}2015- \\
2016\end{array}$ & $\begin{array}{l}2016- \\
2017\end{array}$ \\
\hline \multirow{9}{*}{$\begin{array}{l}\infty \\
\stackrel{\infty}{0} \\
\stackrel{\widetilde{N}}{\mathbb{V}}\end{array}$} & \multirow{3}{*}{$\mathrm{AWD}_{45 \%}$} & N100\% & 9.29 & 8.95 & 2.67 & 2.60 & 2702.2 & 2802.5 \\
\hline & & N80\% & 8.00 & 7.79 & 2.24 & 2.19 & 2702.2 & 2802.5 \\
\hline & & N60\% & 6.70 & 6.73 & 1.94 & 1.95 & 2702.2 & 2802.5 \\
\hline & \multirow{3}{*}{$\mathrm{AWD}_{60 \%}$} & N100\% & 9.36 & 9.19 & 2.80 & 2.76 & 2792.5 & 2678.4 \\
\hline & & N80\% & 8.54 & 8.47 & 2.30 & 2.17 & 2792.5 & 2678.4 \\
\hline & & N60\% & 6.36 & 6.46 & 1.73 & 1.76 & 2792.5 & 2678.4 \\
\hline & \multirow{3}{*}{$\mathrm{AWD}_{70 \%}$} & N100\% & 8.86 & 8.84 & 2.50 & 2.49 & 2879.5 & 2716.4 \\
\hline & & N80\% & 8.47 & 8.41 & 2.35 & 2.31 & 2879.5 & 2716.4 \\
\hline & & N60\% & 6.57 & 6.37 & 1.96 & 1.89 & 2879.5 & 2716.4 \\
\hline \multirow{9}{*}{$\begin{array}{l}\frac{\pi}{\pi} \\
\stackrel{\mathbb{N}}{\mathbb{v}}\end{array}$} & \multirow{3}{*}{$\mathrm{AWD}_{45 \%}$} & N100\% & 11.41 & 10.93 & 3.37 & 3.30 & 2702.2 & 2802.5 \\
\hline & & N80\% & 10.32 & 10.39 & 2.77 & 2.79 & 2702.2 & 2802.5 \\
\hline & & N60\% & 8.28 & 8.36 & 2.32 & 2.34 & 2702.2 & 2802.5 \\
\hline & \multirow{3}{*}{$\mathrm{AWD}_{60 \%}$} & N100\% & 11.75 & 11.62 & 3.43 & 3.39 & 2792.5 & 2678.4 \\
\hline & & N80\% & 10.73 & 10.39 & 3.25 & 3.14 & 2792.5 & 2678.4 \\
\hline & & N60\% & 8.20 & 7.79 & 2.31 & 2.17 & 2792.5 & 2678.4 \\
\hline & \multirow{3}{*}{$\mathrm{AWD}_{70 \%}$} & N100\% & 11.07 & 11.07 & 3.20 & 3.20 & 2879.5 & 2716.4 \\
\hline & & N80\% & 10.66 & 10.66 & 3.23 & 3.23 & 2879.5 & 2716.4 \\
\hline & & N60\% & 8.02 & 7.70 & 2.27 & 2.12 & 2879.5 & 2716.4 \\
\hline
\end{tabular}


Tab. (7): Average of irrigation water and yield components of wheat Giza 168 and 171 versus irrigation regime and nitrogen fertilization.

\begin{tabular}{|c|c|c|c|c|c|c|c|c|c|}
\hline \multirow{2}{*}{$\begin{array}{l}\text { Wheat } \\
\text { variety }\end{array}$} & \multirow{2}{*}{$\begin{array}{l}\text { Water } \\
\text { regime }\end{array}$} & \multirow{2}{*}{$\begin{array}{c}\mathrm{N} \\
\text { fertilizer }\end{array}$} & \multirow{2}{*}{$\begin{array}{c}\text { Average } \\
\text { irrigation } \\
\text { water } \\
\text { m3/fed }\end{array}$} & \multicolumn{3}{|c|}{ Average yield ton/fed } & \multicolumn{3}{|c|}{$\begin{array}{c}\text { Average Water use } \\
\text { efficiency \% }\end{array}$} \\
\hline & & & & Total & Straw & Grain & Total & Straw & Grain \\
\hline \multirow{9}{*}{$\begin{array}{l}\infty \\
\mathbb{O} \\
\frac{\mathbb{N}}{\mathbb{N}} \\
\frac{\mathbb{N}}{U}\end{array}$} & \multirow{3}{*}{$\mathrm{AWD}_{45 \%}$} & N100\% & 2752.30 & 9.12 & 6.49 & 2.63 & 3.32 & 2.36 & 0.96 \\
\hline & & $\mathrm{N} 80 \%$ & 2752.30 & 7.89 & 5.68 & 2.21 & 2.89 & 2.08 & 0.81 \\
\hline & & $\mathrm{N} 60 \%$ & 2752.30 & 6.72 & 4.77 & 1.95 & 2.44 & 1.73 & 0.71 \\
\hline & \multirow{3}{*}{ AWD $60 \%$} & N100\% & 2735.48 & 9.28 & 6.50 & 2.78 & 3.39 & 2.38 & 1.02 \\
\hline & & $\mathrm{N} 80 \%$ & 2735.48 & 7.89 & 5.68 & 2.21 & 2.89 & 2.08 & 0.81 \\
\hline & & N60\% & 2735.48 & 6.41 & 4.66 & 1.74 & 2.34 & 1.71 & 0.64 \\
\hline & \multirow{3}{*}{$\mathrm{AWD}_{70 \%}$} & N100\% & 2797.94 & 8.85 & 6.35 & 2.49 & 3.16 & 2.27 & 0.89 \\
\hline & & N80\% & 2797.94 & 8.44 & 6.11 & 2.33 & 3.02 & 2.18 & 0.83 \\
\hline & & $\mathrm{N} 60 \%$ & 2797.94 & 8.85 & 6.35 & 2.49 & 3.16 & 2.27 & 0.89 \\
\hline \multirow{9}{*}{$\frac{\bar{N}}{\frac{\mathbb{N}}{N}}$} & \multirow{3}{*}{$\mathrm{AWD}_{45 \%}$} & N100\% & 2752.30 & 11.17 & 7.84 & 3.34 & 4.06 & 2.85 & 1.21 \\
\hline & & N80\% & 2752.30 & 10.35 & 7.57 & 2.78 & 3.76 & 2.75 & 1.01 \\
\hline & & $\mathrm{N} 60 \%$ & 2752.30 & 8.32 & 5.99 & 2.33 & 3.02 & 2.18 & 0.85 \\
\hline & \multirow{3}{*}{$\mathrm{AWD}_{60 \%}$} & N100\% & 2735.48 & 11.69 & 8.28 & 3.40 & 4.27 & 3.03 & 1.25 \\
\hline & & N80\% & 2735.48 & 10.56 & 7.36 & 3.19 & 3.86 & 2.69 & 1.17 \\
\hline & & N60\% & 2735.48 & 11.07 & 7.87 & 3.20 & 3.96 & 2.81 & 1.15 \\
\hline & \multirow{3}{*}{ AWD70\% } & N100\% & 2797.94 & 11.07 & 7.87 & 3.20 & 3.96 & 2.82 & 1.14 \\
\hline & & N80\% & 2797.94 & 10.66 & 7.44 & 3.22 & 3.81 & 2.66 & 1.15 \\
\hline & & $\mathrm{N} 60 \%$ & 2797.94 & 7.86 & 5.67 & 2.19 & 2.81 & 2.03 & 0.78 \\
\hline
\end{tabular}




\section{CONCLUSION}

From the obtained results it could be concluded that:

- Seasonal $\mathrm{ET}_{0}$ during the growing season of winter wheat were 665.9 $\mathrm{mm}$ and $624.8 \mathrm{~mm}$ of 2015-2016 and 2016-2017 growing seasons, respectively.

- Wheat crop transpiration was $600.28 \mathrm{~mm}$ during the growing season of 2015- 02016 and changed to $572.95 \mathrm{~mm}$ for the next season.

- The gross irrigation water requirements of wheat were $2702.2 \mathrm{~m}^{3} / \mathrm{fed}$, $2792.6 \mathrm{~m}^{3} / \mathrm{fed}$ and $2879.1 \mathrm{~m}^{3} / \mathrm{fed}$ at $\mathrm{AWD}_{45 \%}, \mathrm{AWD}_{60 \%}$ and $\mathrm{AWD}_{70 \%}$ treatment for the growing season of 2015-2016, respectively, and became $2802.5 \mathrm{~m}^{3} / \mathrm{fed}, 2687.4 \mathrm{~m}^{3} / \mathrm{fed}$ and $2716.4 \mathrm{~m}^{3} / \mathrm{fed}$ at the next growing season.

- Based on the irrigation regimes and water balance by the budget technique, the irrigation events of wheat at $45 \%, 60 \%$ and $70 \%$ depletion treatments were 29, 23 and 21, which required irrigating for 23.17, 23.94 and 24.69 hours in the first season, respectively. The second season results changed to 28,23 and 20 irrigations, which required irrigating for $24.4,22.96$ and 23.29 hours.

- Among all the studied treatments, the maximum wheat grain yield and water use efficiency of wheat regardless of the variety under investigation could be obtained with irrigation at $60 \%$ depletion of the available soil moisture and $100 \%$ of the recommended nitrogen fertilization. The yield and grain water use efficiency of Giza 168 under these conditions were 2.78 ton/fed and $1.02 \mathrm{~kg} / \mathrm{m}^{3}$. While for Giza 171, $3.4 \mathrm{ton} / \mathrm{fed}$ and $1.24 \mathrm{~kg} / \mathrm{m}^{3}$ were obtained with $22.3 \%$ and $21.6 \%$ increase in yield and grain water use efficiency, respectively.

- The results indicated a significant effect of the crop cultivars and nitrogen fertilization levels on biological yield, straw yield, grain yield, WUE of grain yield and WUE of straw yield. The irrigation water regime levels showed no significant effect on the previous parameters.

- The interaction of wheat cultivars, nitrogen fertilization levels and irrigation water regimes showed insignificant effect on biological yield, straw yield, grain yield, WUE of grain yield and WUE of straw yield.

- The water budget as an irrigation scheduling method is applicable in wheat irrigation in sandy soil. 


\section{$\underline{\text { Appendix I }}$}

$$
\begin{aligned}
& R_{a}=1.267\left(\frac{h_{d}}{r_{v}{ }^{2}}\right)\left[h_{s} \frac{\pi}{180} \sin \Phi \sin \delta+\cos \Phi \cos \delta \sinh _{s}\right] \\
& h_{d}=12.126-1.8519 \times 10^{-3} A B S(\Phi)+7.61048 \times 10^{-5}(\Phi)^{2} \\
& r_{v}=0.9839-1.1140 \times 10^{-4} J+5.277 \times 10^{-6} J^{2}-2.6829 \times 10^{-8} J^{3}+3.616 \times 10^{-11} j^{-4} \\
& h_{s}=\cos ^{-1}\left(-\tan ^{-1} \Phi \tan \delta\right) \\
& \delta=23.45 \sin \left(360 \frac{284+J}{365}\right) \\
& \Delta=2\left(0.00738 T_{m}+0.8072\right)^{7}-0.00116 \\
& \gamma=\left[\frac{1615 P_{a}}{2.49 \times 10^{6}-2.13 \times 10^{3} T_{m}}\right] \\
& P_{a}=1013-0.1152 h+5.44 \times 10^{-6} h^{2} \\
& R_{n}=0.75 R_{s}-2 \times 10^{-9}\left(T_{m}+273.16\right)^{4}\left(0.34-0.044 \sqrt{e_{a}}\right)\left(-0.35+1.8 \frac{R_{s}}{R_{a}}\right) \\
& R_{S}=\left(0.25+0.5 \frac{n}{N}\right) R_{a} \\
& f(u)=0.27(1+0.01 U) \\
& e_{s}=33.8639\left[\left(0.00738 T_{m}+0.8072\right)^{8}-0.000019\left|1.8 T_{m}+48\right|+0.001316\right] \\
& e_{a}=e_{s}\left(\frac{R H_{m}}{100}\right)
\end{aligned}
$$

where:

$\mathrm{R}_{\mathrm{a}}$ Extraterrestrial solar radiation (mm/day) estimated according to James (1988).

$\mathrm{h}_{\mathrm{d}} \quad$ Daytime hours at zero declination, (hours)

$r_{v} \quad$ Radius vector of earth

$\mathrm{h}_{\mathrm{s}} \quad$ Sunrise to sunset hour angle (degrees), according to Duffie (1980)

$\Phi \quad$ Latitude, (degrees)

$\delta \quad$ Solar declination, (degrees), according to Duffie (1980)

J Julian day

$\Delta \quad$ Slope of saturation vapor pressure versus temperature curve at mean temperature $\left(\mathrm{mbar} / \mathrm{C}^{\circ}\right)$ estimated according Cuneca (1989).

$\gamma$ Psychometric constant $\left(\mathrm{mbar} / \mathrm{C}^{\circ}\right)$, according to James (1988).

$\mathrm{P}_{\mathrm{a}}$ Atmospheric pressure, (mbar), according to James (1988).

$\mathrm{h} \quad$ Elevation above sea level, $\mathrm{m}$

$R_{s}$ Solar radiation in evaporation equivalents (mm/day) 
$\mathrm{R}_{\mathrm{n}} \quad$ Net radiation equivalent, (mm/day), according to Doorenbos and Pruitt (1977).

f(u) Wind function, according to Doorenbos and Pruirr (1977)

$\Delta \mathrm{e} \quad$ Vapor pressure deficit $\left(\mathrm{e}_{\mathrm{s}}-\mathrm{e}_{\mathrm{a}}\right),($ mbar)

$\mathrm{e}_{\mathrm{s}} \quad$ Saturation vapor pressure at the air temperature, (mbar), according to

Cuenca (1989)

Ea Vapor pressure at mean air temperature (mbar)

$\mathrm{n} / \quad$ Ratio of actual to maximum sunshine hours

$\mathrm{N}$

\section{Appendix II}

Table (1): Effect of the interaction between studied factors on wheat Grain yield and Straw yield.

\begin{tabular}{|c|c|c|c|c|c|c|c|c|}
\hline \multirow{2}{*}{ 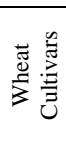 } & \multirow{2}{*}{ 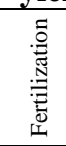 } & \multirow{2}{*}{ 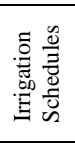 } & \multicolumn{3}{|c|}{$2015 / 2016$} & \multicolumn{3}{|c|}{$2016 / 2017$} \\
\hline & & & $\begin{array}{c}\text { Biological } \\
\text { yield }\end{array}$ & $\begin{array}{l}\text { Grain } \\
\text { yield }\end{array}$ & $\begin{array}{r}\begin{array}{l}\text { Straw } \\
\text { yield }\end{array} \\
\end{array}$ & $\begin{array}{c}\text { Biological } \\
\text { yield }\end{array}$ & $\begin{array}{l}\text { Grain } \\
\text { yield }\end{array}$ & $\begin{array}{r}\text { Straw } \\
\text { yield }\end{array}$ \\
\hline \multirow{3}{*}{$\mathrm{C} 1$} & 1 & & 9.17 & 2.65 & 6.52 & 8.99 & 2.62 & 6.38 \\
\hline & 0.8 & & 8.33 & 2.3 & 6.04 & 8.22 & 2.22 & 6 \\
\hline & 0.6 & & 6.54 & 1.88 & 4.67 & 6.52 & 1.87 & 4.65 \\
\hline \multirow{3}{*}{$\mathrm{C} 2$} & 1 & & 11.41 & 3.33 & 8.08 & 11.21 & 3.3 & 7.91 \\
\hline & 0.8 & & 10.57 & 3.08 & 7.49 & 10.48 & 3.05 & 7.43 \\
\hline & 0.6 & & 8.17 & 2.3 & 5.87 & 7.95 & 2.21 & 5.74 \\
\hline \multicolumn{3}{|c|}{$\mathrm{LSD}_{0.05}$} & Ns & ns & ns & ns & $*$ & $\mathrm{Ns}$ \\
\hline $\mathrm{C} 1$ & & \multirow{2}{*}{$20 \%$} & 8 & 2.28 & 5.71 & 7.83 & 2.25 & 5.58 \\
\hline $\mathrm{C} 2$ & & & 10 & 2.82 & 7.18 & 9.9 & 2.81 & 7.08 \\
\hline $\mathrm{C} 1$ & & \multirow{2}{*}{$25 \%$} & 8.09 & 2.27 & 5.81 & 8.04 & 2.23 & 5.81 \\
\hline $\mathrm{C} 2$ & & & 10.23 & 3 & 7.23 & 9.93 & 2.9 & 7.03 \\
\hline $\mathrm{C} 1$ & & \multirow{2}{*}{$30 \%$} & 7.96 & 2.27 & 5.7 & 7.87 & 2.23 & 5.64 \\
\hline $\mathrm{C} 2$ & & & 9.92 & 2.9 & 7.02 & 9.81 & 2.85 & 6.96 \\
\hline \multicolumn{3}{|c|}{$\mathrm{LSD}_{0.05}$} & Ns & ns & ns & ns & ns & Ns \\
\hline & 1 & \multirow{3}{*}{$20 \%$} & 10.35 & 3.02 & 7.33 & 9.94 & 2.95 & 7 \\
\hline & 0.8 & & 9.16 & 2.51 & 6.65 & 9.09 & 2.49 & 6.6 \\
\hline & 0.6 & & 7.49 & 2.13 & 5.36 & 7.55 & 2.15 & 5.4 \\
\hline & 1 & \multirow{3}{*}{$25 \%$} & 10.56 & 3.11 & 7.45 & 10.4 & 3.07 & 7.33 \\
\hline & 0.8 & & 9.64 & 2.77 & 6.86 & 9.43 & 2.66 & 6.77 \\
\hline & 0.6 & & 7.28 & 2.02 & 5.26 & 7.12 & 1.96 & 5.16 \\
\hline & 1 & \multirow{3}{*}{$30 \%$} & 9.96 & 2.85 & 7.11 & 9.95 & 2.84 & 7.11 \\
\hline & 0.8 & & 9.56 & 2.79 & 6.78 & 9.53 & 2.77 & 6.77 \\
\hline & 0.6 & & 7.3 & 2.11 & 5.18 & 7.04 & 2.01 & 5.03 \\
\hline \multicolumn{3}{|c|}{$\mathrm{LSD}_{005}$} & Ns & $*$ & ns & ns & $*$ & $\mathrm{Ns}$ \\
\hline
\end{tabular}




\begin{tabular}{|c|c|c|c|c|c|c|c|c|}
\hline \multirow{3}{*}{$\mathrm{C} 1$} & 1 & \multirow{6}{*}{$20 \%$} & 9.29 & 2.67 & 6.63 & 8.95 & 2.6 & 6.35 \\
\hline & 0.8 & & 8 & 2.24 & 5.75 & 7.79 & 2.19 & 5.6 \\
\hline & 0.6 & & 6.7 & 1.94 & 4.76 & 6.73 & 1.95 & 4.78 \\
\hline \multirow{3}{*}{$\mathrm{C} 2$} & 1 & & 11.41 & 3.37 & 8.04 & 10.93 & 3.3 & 7.63 \\
\hline & 0.8 & & 10.32 & 2.77 & 7.54 & 10.39 & 2.79 & 7.6 \\
\hline & 0.6 & & 8.28 & 2.32 & 5.97 & 8.36 & 2.34 & 6.02 \\
\hline \multirow{3}{*}{$\mathrm{C} 1$} & 1 & \multirow{6}{*}{$25 \%$} & 9.39 & 2.8 & 6.57 & 9.19 & 2.76 & 6.43 \\
\hline & 0.8 & & 8.54 & 2.3 & 6.25 & 8.47 & 2.17 & 6.3 \\
\hline & 0.6 & & 6.36 & 1.73 & 4.63 & 6.46 & 1.76 & 4.7 \\
\hline \multirow{3}{*}{$\mathrm{C} 2$} & 1 & & 11.75 & 3.43 & 8.33 & 11.62 & 3.39 & 8.23 \\
\hline & 0.8 & & 10.73 & 3.25 & 7.48 & 10.39 & 3.14 & 7.24 \\
\hline & 0.6 & & 8.2 & 2.31 & 5.97 & 7.79 & 2.17 & 5.62 \\
\hline \multirow{3}{*}{$\mathrm{C} 1$} & 1 & \multirow{6}{*}{$30 \%$} & 8.86 & 2.5 & 6.36 & 8.84 & 2.49 & 6.35 \\
\hline & 0.8 & & 8.47 & 2.35 & 6.12 & 8.41 & 2.31 & 6.1 \\
\hline & 0.6 & & 6.57 & 1.96 & 4.61 & 6.37 & 1.89 & 4.48 \\
\hline \multirow{3}{*}{ C2 } & 1 & & 11.07 & 3.2 & 7.87 & 11.07 & 3.2 & 7.87 \\
\hline & 0.8 & & 10.66 & 3.23 & 7.44 & 10.66 & 3.23 & 7.44 \\
\hline & 0.6 & & 8.02 & 2.27 & 5.76 & 7.7 & 2.12 & 5.58 \\
\hline \multicolumn{3}{|c|}{$\mathrm{LSD}_{0.05}$} & Ns & ns & ns & ns & ns & Ns \\
\hline
\end{tabular}

ns: not significant based on $\mathrm{LSD}_{0.05}$.

Table (2): Effect of wheat cultivars, fertilization and irrigation regime on water use efficiency.

\begin{tabular}{|c|c|c|c|c|c|c|}
\hline \multirow{3}{*}{ 吾 } & \multirow{3}{*}{ 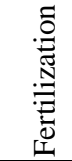 } & \multirow{3}{*}{ 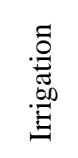 } & \multicolumn{2}{|c|}{$2015 / 2016$} & \multicolumn{2}{|c|}{$2016 / 2017$} \\
\hline & & & WUE & WUE & WUE & WUE \\
\hline & & & $\mathrm{Kg} \mathrm{G} / \mathrm{m}^{3}$ & $\mathrm{Kg} \mathrm{S} / \mathrm{m}^{3}$ & $\mathrm{Kg} \mathrm{G} / \mathrm{m}^{3}$ & $\mathrm{Kg} \mathrm{S} / \mathrm{m}^{3}$ \\
\hline \multirow{3}{*}{$\mathrm{C} 1$} & 1 & & 0.95 & 2.34 & 0.96 & 2.33 \\
\hline & 0.8 & & 0.82 & 2.16 & 0.81 & 2.2 \\
\hline & 0.6 & & 0.67 & 1.67 & 0.68 & 1.7 \\
\hline \multirow{3}{*}{$\mathrm{C} 2$} & 1 & & 1.2 & 2.9 & 1.21 & 2.9 \\
\hline & 0.8 & & 1.1 & 2.68 & 1.12 & 2.72 \\
\hline & 0.6 & & 0.82 & 2.11 & 0.81 & 2.1 \\
\hline \multicolumn{3}{|c|}{$\mathrm{LSD}_{0.05}$} & ns & ns & $*$ & Ns \\
\hline $\mathrm{C} 1$ & & \multirow{2}{*}{$20 \%$} & 0.85 & 2.11 & 0.8 & 2 \\
\hline $\mathrm{C} 2$ & & & 1.04 & 2.66 & 1 & 2.53 \\
\hline $\mathrm{C} 1$ & & \multirow{2}{*}{$25 \%$} & 0.81 & 2.08 & 0.83 & 2.17 \\
\hline $\mathrm{C} 2$ & & & 1.07 & 2.59 & 1.08 & 2.63 \\
\hline $\mathrm{C} 1$ & & \multirow{2}{*}{$30 \%$} & 0.79 & 1.98 & 0.82 & 2.08 \\
\hline $\mathrm{C} 2$ & & & 1.01 & 2.44 & 1.05 & 2.56 \\
\hline \multicolumn{3}{|c|}{$\mathrm{LSD}_{0.05}$} & ns & ns & ns & Ns \\
\hline
\end{tabular}




\begin{tabular}{|c|c|c|c|c|c|c|}
\hline & 1 & \multirow{3}{*}{$20 \%$} & 1.12 & 2.71 & 1.05 & 2.5 \\
\hline & 0.8 & & 0.93 & 2.46 & 0.89 & 2.36 \\
\hline & 0.6 & & 0.79 & 1.98 & 0.77 & 1.93 \\
\hline & 1 & \multirow{3}{*}{$25 \%$} & 1.11 & 2.67 & 1.15 & 2.74 \\
\hline & 0.8 & & 0.99 & 2.46 & 0.99 & 2.53 \\
\hline & 0.6 & & 0.72 & 1.88 & 0.73 & 1.93 \\
\hline & 1 & \multirow{3}{*}{$30 \%$} & 0.99 & 2.47 & 1.05 & 2.62 \\
\hline & 0.8 & & 0.97 & 2.35 & 1.02 & 2.49 \\
\hline & 0.6 & & 0.73 & 1.8 & 0.74 & 1.85 \\
\hline \multicolumn{3}{|c|}{$\mathrm{LSD}_{0.05}$} & $*$ & ns & $*$ & Ns \\
\hline \multirow{3}{*}{$\mathrm{C} 1$} & 1 & \multirow{6}{*}{$20 \%$} & 0.99 & 2.45 & 0.93 & 2.27 \\
\hline & 0.8 & & 0.83 & 2.13 & 0.78 & 2 \\
\hline & 0.6 & & 0.72 & 1.76 & 0.7 & 1.71 \\
\hline \multirow{3}{*}{$\mathrm{C} 2$} & 1 & & 1.25 & 2.97 & 1.18 & 2.72 \\
\hline & 0.8 & & 1.03 & 2.79 & 1 & 2.71 \\
\hline & 0.6 & & 0.86 & 2.21 & 0.84 & 2.15 \\
\hline \multirow{3}{*}{$\mathrm{C} 1$} & 1 & \multirow{6}{*}{$25 \%$} & 1 & 2.35 & 1.03 & 2.4 \\
\hline & 0.8 & & 0.82 & 2.24 & 0.81 & 2.35 \\
\hline & 0.6 & & 0.62 & 1.66 & 0.66 & 1.76 \\
\hline \multirow{3}{*}{$\mathrm{C} 2$} & 1 & & 1.23 & 2.98 & 1.26 & 3.07 \\
\hline & 0.8 & & 1.16 & 2.68 & 1.17 & 2.71 \\
\hline & 0.6 & & 0.83 & 2.11 & 0.81 & 2.1 \\
\hline \multirow{3}{*}{$\mathrm{C} 1$} & 1 & \multirow{6}{*}{$30 \%$} & 0.87 & 2.21 & 0.92 & 2.34 \\
\hline & 0.8 & & 0.82 & 2.12 & 0.85 & 2.25 \\
\hline & 0.6 & & 0.78 & 1.6 & 0.7 & 1.65 \\
\hline \multirow{3}{*}{$\mathrm{C} 2$} & 1 & & 1.11 & 2.73 & 1.18 & 2.9 \\
\hline & 0.8 & & 1.12 & 2.58 & 1.19 & 2.74 \\
\hline & 0.6 & & 0.79 & 2 & 0.78 & 2.05 \\
\hline \multicolumn{3}{|c|}{$\operatorname{LSD}_{0.05}$} & ns & ns & ns & Ns \\
\hline
\end{tabular}

ns: not significant based on $\mathrm{LSD}_{0.05}$.

\section{DEDICATION}

We dedicate this work to the spirit of Dr. Khalil Allam who started this work and then died in a terrible accident while performing his duty in Sinai. 


\section{REFERENCES}

Abdelmageed, K., CHANG, X. H., WANG, D. M., WANG, Y. J., YANG, Y. S., ZHAO, G. C. and Z. Q. TAO (2019). Evolution of varieties and development of production technology in Egypt wheat: A review. J. Integr. Agri., 18(3): 483-495.

Abdelraouf, R. E., M. E. Ahmed, B. A. Bakry and M. KH. Elbegawy (2014). Effect of Sprinkler Irrigation Systems and Irrigation Frequency on Water Use Efficiency and Economical Parameters for Wheat Production. International Journal of Scientific Research in Agricultural Sciences, 1(4): 56-66.

Adeboye, O., B. Schultz, K. Adekalu and K. Prasad (2015). Crop water productivity and economic evaluation of drip-irrigated soybeans (Glyxine max L. Merr.). Agriculture and Food Security, 4(10): 1-13.

Allen, R. G., Pereira, L. S., Raes, D. and M. Smith (1998). Crop evapotranspiration-Guidelines for computing crop water requirements. FAO Irrigation and drainage paper 56. FAO, Rome, 300(9), p.D05109.

ASAE 1988: Engineering Practices and Data Adopted by the American Society of Agricultural Engineers, Volume 2002. The University of Wisconsin - Madison.

Berry, A. M., G. A. Sharaf, Azza Hassan and Ebtsam Sebaaee (2004). Irrigation scheduling of sunflower with drip irrigation system in newly reclaimed land. Misr J. Ag. Eng., 20(4): 993-1010.

Black, C. A., D. D. Evans, L. E. Ensminger, J. L. White, F. E. Clark and R. C. Dinauer (1982). Methods of soil analysis. 7th Ed. The Am. Soc. of Agron. Madison, Wisc., USA

CoHort Software (2005). Costat Statistical package (version 6.311), P.O.Box 1149, Berkeley, CA, 94701, USA.

Cuenca, R. H. (1989). Irrigation System Design: An Engineering Approach. Prentice Hall, pp552. 
Doorenbos, J. and W.O. Pruit (1977). Guidelines for predicting crop water requirements FAO, irrigation and drainage paper No. 24. FAO, United Nation, Rome.

Duffie, J. A. and W. A. Beckman, (1980). Solar engineering of thermal processes, John Wiley, Sons; New york.

Duke, H. R., G. W. Buchleiter and D. F. Heermann (1985). Evapotranspiration Theory USDA Agric. Res. Service: 11.

El-Kholy, M. A., S. A. Ouda, M. S. Gaballah and M. Hozayn (2005). Predicting the interaction between the effect of anti-transpirant and weather on productivity of wheat plant grown under water stress. Journal of Agronomy, 4: 75-82.

Faostat, F.A.O. (2017). FAO open data. Available online at: FAO web site http://www.fao.org/faostat/en/\#data, accessed on January 2018.

James, L. M. (1988). Principles of farm irrigation system design. John Wiley Sons: 543 pp.

Jensen, M. E. (1983). Design and operation of farm irrigation systems. Am. Soc. Ag. Eng. Joseph, Michigan.: pp819-820.

Kayam, Y., Beyazgül, M. and A. Yazar (2000). Use of Infrared Thermometer Technique in Irrigation Scheduling of Cotton Plant. Soil and Water Resources Research, pp. 312-326.

Noreldin, T., S. Ouda, O. Mounzer and M. T. Abdelhamid (2015). CropSyst model for wheat under deficit irrigation using sprinkler and drip irrigation in sandy soil. Journal of Water and Land Development, 26: 57-64.

Odemiş, B. and R. Bastug (1999). Assessing crop water stress and irrigation scheduling in cotton through use of infrared thermometry technique. Turk. J. Agric. For. 23: 31-37.

World Bank, T. (2018). World Bank open data. Available online at: World Bank Web site https://www.worldbank.org/, accessed on June 2019. 


\section{الملخص العربي \\ تأثز إنتاجية محصول القمح \\ بحدود جدولة الري ومستويات التسميا النيتروجينى التمديح

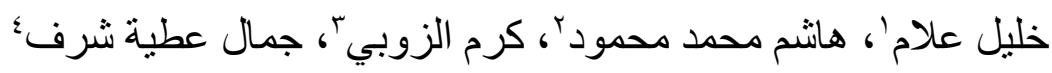

أجريت الدراسة الحالية بمنطقة بحري الميثاق بمنطقة برج العرب غرب الاسكندرية، وكان الغرض من إجراء هذا البحث هو دراسة تأثير مستويات مختلفة من جدولة الرى و التسميد

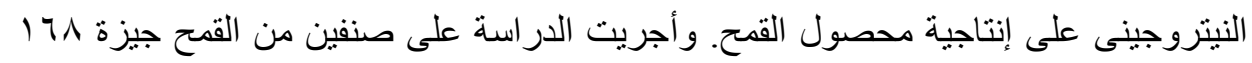

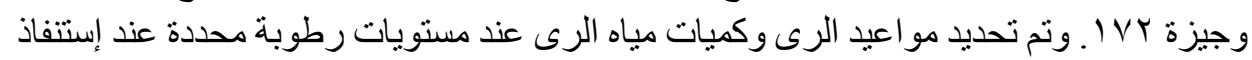

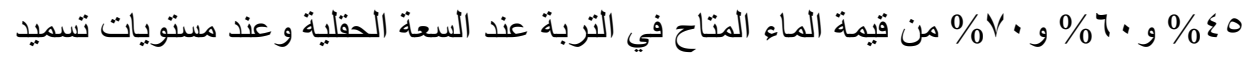

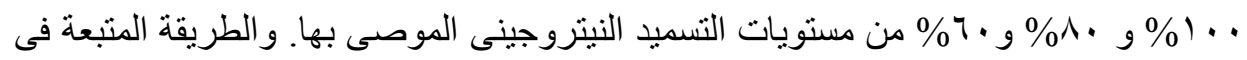
جدولة الرى وتحديد كميات المياه المطلوبة وزمن التشغيل لنظام الرى بالرش هـى الاتز ان المائى.

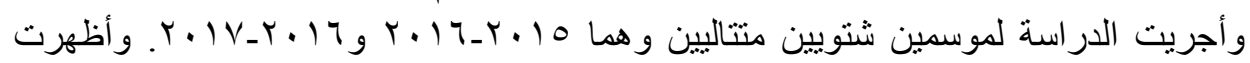

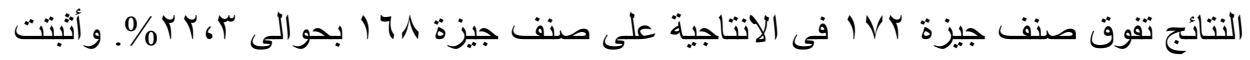
الدر اسة أنه للحصول على أقصى إنتاجية من محصول القمح تحت ظروف التجربة هو الرفى على عند

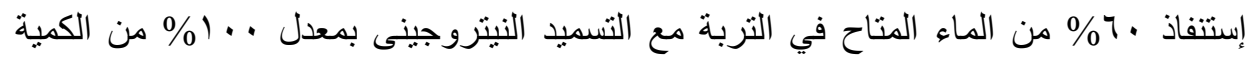

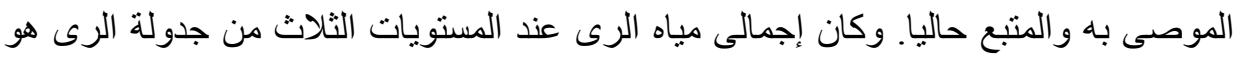

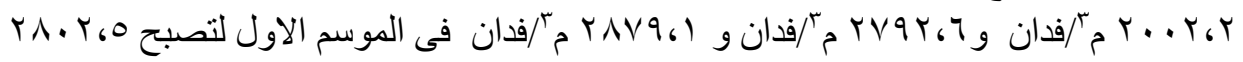

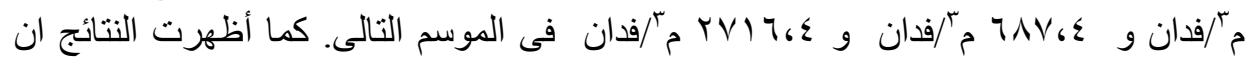

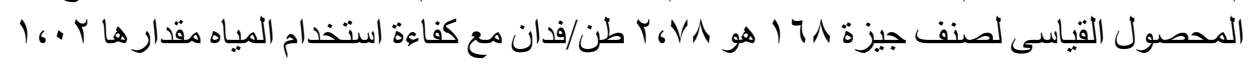

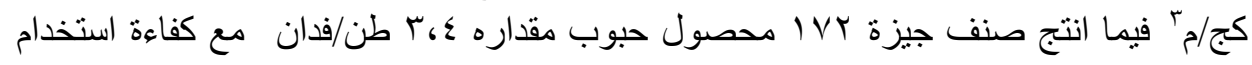

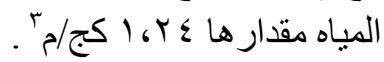

'رئيس بحوث سابقاً ـ بباحث - مركز البحوث الزراعية، معهذ بحوث الهندسة الزراعية، القاهرة، مصر.

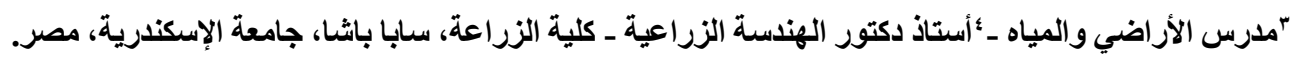

